\title{
Artificial cooling as an alternative to increase productivity and welfare of steers under heat stress
}

[Resfriamento artificial como alternativa para aumentar o bem-estar de novilhos sob estresse térmico]

\author{
A. Correa-Calderón ${ }^{1}$, M. Morales $^{1}$, L. Avendaño ${ }^{1}$, C. Leyva ${ }^{1}$, F. Rivera ${ }^{1}$, R. Díaz ${ }^{2}$, S. Soto-Navarro ${ }^{3}$ \\ ${ }^{1}$ Instituto de Ciencias Agrícolas \\ ${ }^{2}$ Facultad de Medicina \\ Universidad Autónoma de Baja California - Mexicali, México \\ ${ }^{3}$ Department of Animal and Range Sciences - New Mexico State University - Las Cruces, NM, USA
}

\begin{abstract}
The effects of a cooling system on productive efficiency and welfare of Holstein steers were evaluated during the summer. Sixty steers in the finishing phase were randomly allotted to one of two treatment-groups. Animals of control group were only provided with shade (non-cooled group) and a group of animals under a cooling system were installed in the shaded area (cooled group), which were operated daily from 09am to 6pm during the $69 \mathrm{~d}$ of the study. The averages of environmental temperature and relative humidity were $35.4^{\circ} \mathrm{C}$ and $35.3 \%$, respectively, with a temperature-humidity index average of 81.4 during the study. Individual body weight was recorded every two weeks, while body surface temperature and respiratory frequency were recorded three times per week. Blood samples were biweekly taken from coccygeal vein for determination of $\mathrm{T}_{3}$ and $\mathrm{T}_{4}$. The average daily gain in the cooled group gain $(1.46 \mathrm{~kg} / \mathrm{d})$ was similar $(\mathrm{P}=0.21)$ to non-cooled group $(1.37 \mathrm{~kg} / \mathrm{d})$. Body surface temperature $\left(35.9^{\circ} \mathrm{C}\right.$ vs $\left.38.7^{\circ} \mathrm{C}\right)$ and respiratory frequency per minute $(77$ vs 104$)$ were lower $(\mathrm{P}<0.01)$ in the cooled group than in non-cooled group, respectively. Triiodotironine levels were similar $(\mathrm{P}=0.30)$ in cooled $(0.80 \mathrm{ng} / \mathrm{mL})$ and non-cooled $(0.87 \mathrm{ng} / \mathrm{mL})$ groups, while, tiroxine level was lower $(P<0.01)$ in cooled group $(44.0 \mathrm{ng} / \mathrm{mL})$ compared to non-cooled group $(56.6 \mathrm{ng} / \mathrm{mL})$. The cooling system did not improve productive parameters but the welfare in the cooled group was increased.
\end{abstract}

Keywords: steer, cooling system, feedlot, heat stress, performance

\section{RESUMO}

Avaliou-se um sistema de resfriamento para aumentar a eficiência produtiva e o bem-estar de novilhos durante o verão. Utilizaram-se 60 animais em fase de acabamento, distribuídos aleatoriamente em dois grupos: os do grupo-controle permaneceram somente sob sombra (grupo não resfriado) e os do grupo sob sistema de resfriamento, sob área sombreada, diariamente, das 9 às 18h, durante 69 dias de estudo. As médias registradas de temperatura ambiente e umidade relativa foram $35,4^{\circ} \mathrm{C}$ e $35,3^{\circ} \mathrm{C}$, respectivamente, com indice de temperatura-umidade de 81,4 durante o período de estudo. $O$ peso individual foi anotado a cada duas semanas, e a temperatura da superfície corporal e a frequência respiratória foram registrados três vezes por semana. Amostras de sangue foram tomadas da veia coccígea duas vezes por semana para determinação de $T_{3}$ $e T_{4}$. O ganho médio diário no grupo sob resfriamento $(1,46 \mathrm{~kg} /$ dia $)$ foi similar $(P=0,21)$ ao do grupo-controle $(1,37 \mathrm{~kg} /$ dia $)$. A temperatura da superfície corporal $\left(35,9^{\circ} \mathrm{C}\right.$ versus $\left.38,7^{\circ} \mathrm{C}\right)$ e a frequência respiratória/minuto (77 versus 104) foram mais baixas $(P<0,01)$ no grupo sob resfriamento do que no grupo-controle $(P<0,01)$, respectivamente. Niveis de triiodotironina foram similares $(P=0,30)$ em animais com resfriamento $(0,80 \mathrm{ng} / \mathrm{mL})$ e sem resfriamento $(0,87 \mathrm{ng} / \mathrm{mL})$, enquanto o nível de tiroxina foi mais baixo $(P<0,01)$ no grupo com resfriamento $(44,0 \mathrm{ng} / \mathrm{mL}$ versus $56,6 \mathrm{ng} / \mathrm{mL})$. O sistema de resfriamento não afetou parâmetros produtivos, porém o bem-estar dos animais do grupo com resfriamento foi melhor.

Palavras-chave: novilho, sistema de resfriamento, confinamento, estresse, desempenho

Recebido em 3 de agosto de 2009

Aceito em 20 de agosto de 2010

E-mail: acorrea@uabc.mx 


\section{INTRODUCTION}

Environmental conditions during the summer can negatively impact feedlot cattle performance (Davis et al., 2003), mainly during the finishing phase because the thermal heat reduces feed intake (Hahn, 1999). High environmental temperature and lack of conditioning to those temperatures can result in significant losses in confined beef cattle. In the summer of 1999, it was estimated that more than 5,000 cattle died only in the state of Nebraska, USA, with total production losses of US\$31 million (Mader et al., 2001). Alternatives to reduce heat stress are very important. St-Pierre et al. (2003) reported that without heat abatement, total losses considering animal classes averaged US\$2.4 billion annually in the USA, while, an optimum heat abatement intensity could potentially reduce annual total losses to US\$1.7 billion. These findings point to a need for more energy and capital efficient heat abatement systems.

The rate of evaporative heat loss from the skin can be increased by wetting the hair coat and skin with water and by using fans to provide forced ventilation (Garner et al., 1989). Studies conducted in the Imperial Valley, California, demonstrated that sprinkling beef cattle under shades during summer increased feed intake and rate of gain compared with cattle under shade and not sprinkled (Morrison et al., 1973). Recently, Correa-Calderón et al. (2007) reported a higher daily gain in cooled Holstein steers compared to only shaded steers in the Mexicali Valley, Mexico. However, it has been noted that performance did not always improve with shade and water misting (Mitlöhner et al., 2001) or even declined with sprinkling (Morrison et al., 1974). Strategies as artificial cooling can alter the pattern of body temperature and improve overall summertime feedlot performance and welfare.

Cattle respond to heat stress reducing feed intake and adversely affect thyroid hormones production to decrease metabolism and consequently internal heat production. However, artificial cooling can increase thyroid gland activity under heat stress conditions (CorreaCalderón et al., 2004a).

The objective of this study was to evaluate the effects of a spray and fans cooling system on performance and welfare (measured by the changes in respiratory frequency, body surface temperature, and thyroid hormones levels) of Holstein steers under heat stress.

\section{MATERIAL AND METHODS}

The study was conducted during 69d from July to September in a commercial feedlot located at Mexicali Valley, Mexico. The Mexicali Valley has very hot and dry conditions, reaching $50^{\circ} \mathrm{C}$ during summer and minimum temperatures of $5^{\circ} \mathrm{C}$ in winter, with precipitation averages of approximately $85 \mathrm{~mm} /$ year (Garcia, 1985).

Sixty Holstein steers in their finishing phase were randomly allotted in two treatments. A control treatment consisted of only shade in the center of the pen (non-cooled group; $n=30$ ). The other treatment consisted of steers with shade similar to control treatment plus spray and fans under the shade (cooled group; $n=30$ ). All the steers had free access to drinking water and were fed with a total mixed ration twice daily (6am and $6 \mathrm{pm})$. Ingredients and chemical components of the diet are shown in Table 1.

The cooling system consisted of six fans $(0.9 \mathrm{~m}$ diameter) with a $0.5 \mathrm{Hp}$ motor producing $180 \mathrm{~m}^{3} / \mathrm{min}$ of air movement. Eight nozzles were installed in front of each fan and sprayed 52 liters of water per hour. The cooling system was controlled by timers and operated from 9am to $6 \mathrm{pm}$. The size of each pen was $660 \mathrm{~m}^{2}$ $\left(22 \mathrm{~m}^{2} /\right.$ steer $)$ and the fences were metal pipe connected with steel cables. The shaded area was $3.8 \mathrm{~m}^{2} /$ steer and the roof shade was galvanized steel sheets. The concrete feed bunk, in each pen, was $27 \mathrm{~m}$ long located in the north side of the pen. At the time of the reception into the feedlot, steers were implanted with RevalorG ${ }^{\circledR}$ (40mg trembolone acetate and $8 \mathrm{mg}$ of $17 \beta$ estradiol; Intervet Animal Health, Millsboro, DE, USA), treated for parasites with Rank® LA (Ivermectine 1\%; Intervet, Brasil), vaccinated with Bovi-Shield 4® (IBR, PI3, BRSV, DVB, Pfizer Inc. Lincoln, NE, USA), and received injections of Aderovet ${ }^{\circledR}$ (vitamins A, D, and E; Intervet, Aprilia, Italy). The steers were reimplanted at $370 \mathrm{~kg}$ with Synovex plus ${ }^{\circledR}(200 \mathrm{mg}$ trembolone acetate and $28 \mathrm{mg}$ estradiol benzoate; Fort Dodge, Websa, FL, USA). 
Table 1. Ingredients and nutrients of the diet fed to experimental steers ${ }^{\mathrm{a}}$

\begin{tabular}{lc}
\hline Ingredient & $(\%)$ \\
\hline Ground hay (50\% Bermuda grass; 50\% alfalfa) & 6 \\
Cottonseed hulls & 12 \\
Dry-rolled wheat & 68 \\
Premix & 2 \\
Molasses & 7 \\
Fat & 5 \\
Chemical components & \\
Dry matter & 87.71 \\
Ether extract & 9.81 \\
Crude protein & 12.29 \\
Ash & 5.27 \\
Neuter detergent fiber & 32.55 \\
Tabular NE, Mcal/kg & 2.00 \\
Tabular NE, Mcal/kg & 1.34 \\
\hline
\end{tabular}

${ }^{\mathrm{a}} \mathrm{DM}$ basis. Net energy values of the diet were calculated from NRC (Nutrient..., 1996) tabular values.

${ }^{\mathrm{b}}$ Crude protein: $48 \%$; Ca: 14\%; K: $1.55 \%$; Mg: 0.28\%; Na: 2\%; S: 0.08\%; Co0:.195\%; Cu: 10.5mg; I: $11 \mathrm{mg}$; Fe: 260mg; Mn: 1100mg, Se: 4.5mg; Zn: 39mg; vit.A: 150,000IU; vit.D: 30,000IU.

Individual body weight (BW) was biweekly determined using a single animal scale. The experiment was conducted in a commercial feedlot and was not possible to have replicates for feed intake, consequently, it was measured twice a week per pen based on the difference in weight of the feed offered and rejected during a $24 \mathrm{~h}$ period.

Blood samples were taken in ten animals per treatment from the coccygeal vein every two weeks at $6 \mathrm{am}$ using $10 \mathrm{~mL}$ vacutainer tubes without anticoagulant. Once collected, the samples were transported on ice to the laboratory and centrifuged at $3,500 \mathrm{xg}$ for $15 \mathrm{~min}$ and the resulting serum frozen $\left(-10^{\circ} \mathrm{C}\right)$. Serum samples were later used to determine total $\mathrm{T}_{3}$ (triiodotironine) and $\mathrm{T}_{4}$ (tiroxine) levels by ELISA $\left(\right.$ Biokwitech $\left.^{\circledR}\right)$. Respiratory frequency (flanks movement per minute) was recorded three times per week at $3 \mathrm{pm}$ in ten animals per treatment. Blood samples and respiratory frequencies throughout the study were taken in the same ten animals each time. Body surface temperature on the neck area $(4 \mathrm{pm})$ was established in all the animals via infrared gun $\left(\right.$ Raytec $^{\circledR}$ ) three times per week

Hourly, ambient temperature and relative humidity were recorded at UABC meteorological station located $15 \mathrm{~km}$ from the study site. These data were used to calculate the temperaturehumidity index according to West (1994).
$\mathrm{THI}=\mathrm{Td}-(0.55-0.55 \times \mathrm{RH})(\mathrm{Td}-58)$, in which:

$\mathrm{THI}=$ temperature-humidity index; $\mathrm{Td}=$ dry bulb temperature $\left({ }^{\circ} \mathrm{F}\right) ; \quad \mathrm{RH}=$ relative humidity/100.

The daily weight gain, hormone levels, respiratory frequency, and body surface temperature were analyzed with repeated measurements by using the repeated statement in the mixed procedure of SAS/2004. The initial weight was used as covariate to adjust daily weight gain. The Fisher Exact Test (Steel and Torrie, 1981) was used for mortality study measured as percentage. Due to lack of repetitions in feed intake, it was not statistically analyzed and only general means were estimated.

\section{RESULTS AND DISCUSSION}

The Mexicali Valley is characterized by high ambient temperatures during the day and night producing unfavorable conditions for the livestock. Climatic conditions during the trial were generally typical for the area with high air temperature and THI for the daytime and night (Table 2). High ambient temperatures for long time can reduce the ability of beef cattle to dissipate body heat to the environment. Mader et al. (2002) reported that THI of 74 is the critical value at which heat stress affects feedlot cattle performance. The opportunity of cattle to lose body heat is increased at night; however, this is 
dependent not only on temperature but also on relative humidity at night. Normally, the relative humidity is lower during daytime hours, but reaches maximum at nighttime (Davis et al., 2003), maintaining heat stress conditions during the night. In the present study, the THI during the day and night exceeded to 74 , which could have maintained the steers under a constant heat stress. A contributing factor to cattle deaths is a continuous exposure to THI values above 70 , with no opportunity for recovery at night. The animals more vulnerable to death are those nearing market weight, new entrants to the feedlot, and sick ones (Nienaber and Hahn, 2004).

Table 2. Climatic measures recorded during the study

\begin{tabular}{lccc}
\hline Item & Day $^{\mathrm{a}}$ & Night $^{\mathrm{b}^{\mathrm{C}}}$ & Daily average \\
\hline Dry bulb temperature, ${ }^{\circ} \mathrm{C}$ & 38.3 & 31.5 & 35.4 \\
Relative humidity, $\%$ & 29.2 & 45.6 & 35.3 \\
Temperature-humidity index & 83.6 & 78.8 & 81.4 \\
\hline
\end{tabular}

${ }^{\mathrm{a} D a y:}$ 7am - 7pm

bight: $8 \mathrm{pm}-6 \mathrm{am}$

Performance data are presented in Table 3. Neither the final BW $(\mathrm{P}=0.90)$ nor the daily weight gain $(\mathrm{P}=0.21)$ were affected by the cooling. Two steers $(500 \mathrm{~kg}$ of body weight each one) suddenly died in the non-cooled group (6.6\% of mortality) and this loss was attributed to heat stress, and no mortality in the cooled group was observed $(\mathrm{P}=0.24)$. Alternatives to reduce heat stress in beef cattle rarely include cooling systems because it is apparently not profitable. However, there are numerous cooling practices in dairy cattle to reduce milk production losses. Some of the dairy applications might be feasible for use in shade structures in beef animals (Nienaber and Hahn, 2004). Previous studies also conducted in the Mexicali Valley, cooling Holstein steers with an open space cooling system, reported no differences between cooled and non-cooled steers (CorreaCalderón et al., 2004b) or higher daily gain in cooled steers (Correa-Calderón et al., 2007).

Table 3. Feedlot performance of cooled and non-cooled steers

\begin{tabular}{lcccc}
\hline Item & Cooled & Non-Cooled & SEM & P-value \\
\hline Number of steers & 30 & 28 & - & \\
Initial BW, kg & 431.1 & 437.0 & 6.1 & 0.50 \\
Final BW, kg & 532.4 & 531.9 & 7.4 & 0.90 \\
ADG, kg & 1.46 & 1.37 & 0.05 & 0.21 \\
Mortality, $\%$ & 0.0 & 6.6 & - & 0.24 \\
\hline
\end{tabular}

ADG: average daily gain.

In the present study, the general means for feed intake were 8.87 and $9.59 \mathrm{~kg} / \mathrm{d}$ for the cooled and non-cooled groups, respectively. Summer heat load causes a reduction in feed and energy intake (Hahn, 1999). Environmental manipulation can lessen this effect, but different results have been reported with this management practice (Garner et al., 1989; Mitlöhner et al., 2001; Correa et al., 2004b). However, a reduction in feed intake during summer can be positive because can effectively decrease basal metabolic heat production (Carstens et al., 1989) and therefore reduce the level of heat stress. In this study, the dry feed intake in the cooled group was $8.2 \%$ less and this could reduce the susceptibility of the steers to heat stress because lowering ME intake can lower body temperature. Davis et al. (2003) reported that altering feeding regimen and sprinkling cattle significantly decreased feedlot cattle heat stress. On the other hand, Mader et al. (2002) reported that limit-feeding feedlot cattle during early summer is a successful tool for enhancing animal comfort by alleviating the combined effects of a high climatic and metabolic heat load. However, the producers are reluctant to impose potential performance losses resulting from feed restriction (Nienaber and Hahn, 2004).

Table 4 shows physiological and thyroid hormones responses to the treatments. Respiratory frequency and body surface 
temperature were used as indicators of comfort level in the steers and means of both variables were higher $(\mathrm{P}<0.01)$ in the non-cooled steers. Even though, the cooling system increased the comfort, the cooled steers did not get the values recorded under thermoneutral conditions for respiratory frequency ( $<60$ breaths per minute) and body surface temperature $\left(\leq 35^{\circ} \mathrm{C}\right)$, indicating a partial alleviation of heat stress by the cooling system. Increased respiratory frequency leads to higher energy use, consequently increasing daily energy requirements by 7 to $25 \%$ (Effect...,
1981). The reduction in respiratory frequency in this study diminished the energy expense used for panting, consequently, more energy could be destined for weight gain, as was showed by the numerical difference for daily gain between treatments. In the present study, respiratory frequency was significantly lower in the cooled steers, which agrees with other trials conducted with beef cattle under heat stress using an open space cooling (Correa-Calderón et al., 2007) or misting (Mitlöhner et al., 2001).

Table 4. Hormonal and physiological responses of cooled and non-cooled steers

\begin{tabular}{lcccc}
\hline Item & Cooled & Non-cooled & SEM & P-value \\
\hline Body surface temperature, ${ }^{\circ} \mathrm{C}$ & 35.9 & 38.7 & 0.17 & 0.01 \\
Respiratory frequency, breaths/min & 77.0 & 104.0 & 1.63 & 0.01 \\
Triiodotironine, $\mathrm{ng} / \mathrm{mL}$ & 0.80 & 0.87 & 0.04 & 0.30 \\
Tiroxine, $\mathrm{ng} / \mathrm{mL}$ & 44.0 & 56.6 & 1.80 & 0.01 \\
\hline
\end{tabular}

Changes in respiratory frequency generally led changes in body temperature by two hours (Eigenberg et al., 2002). Increasing body temperature is delayed by increased respiratory frequency. Compared to body temperature, variations in measurements of respiratory frequency among animals were lower, making it a good indicator of thermal stress (Brown-Brandl et al., 2002).

Rectal temperature record is difficult because the animals had to be handled to take the measurements. This process might affect rectal temperature and confound the results (Mitlöhner et al., 2001). Recently, infrared thermography has shown to be a low cost approach to estimate actual skin surface temperature of animals. Infrared skin temperature is highly correlated with respiration rate and core temperature and is a good measure of the microenvironment around the animal. Furthermore, the measurement can be taken from a distance, which does not require restricting movement of the animals. If the skin surface temperature is below $35^{\circ} \mathrm{C}$, the temperature gradient between the core and skin is large enough for the animals to effectively use all routes of heat exchange (Collier et al., 2006). In this study, the cooling system considerably reduced the surface temperature compared to the animals with only shade; however, that reduction was not enough to maintain the surface temperature normal $\left(35^{\circ} \mathrm{C}\right)$, probably because the cooling system only partially reduced the heat stress.

Triiodotironine level in serum was similar between treatments $(\mathrm{P}=0.30)$; however, tiroxine level was higher $(\mathrm{P}=0.01)$ in the non-cooled group compared to cooled group. As previously described, the main response of cattle to heat stress is to reduce feed intake in an effort to decrease metabolism and consequently internal heat production. This reduced feed intake in conjunction with high environmental temperatures may adversely affect production of thyroid hormones (McGuirre et al., 1991). Thyroid activity can be altered when cattle are exposed to heat stress by shade (Collier et al., 1982) or cooling (Correa-Calderon et al., 2004a). However, in this study, the response was opposite to that found in other studies, because a higher level of $\mathrm{T}_{4}$ was observed in the noncooled group. The response of thyroid hormones to high environmental temperatures during the summer may be influenced by different factors. Hersom et al. (2004ab) indicated that factors as diet, finishing feeding protocol, timing of placement into the feedlot, feeding frequency, and compensatory growth increased the variation in metabolites and hormones in beef cattle. There is evidence that estrogenic compounds increase plasma concentration of $\mathrm{T}_{4}$ (Trenkle, 1997). Also, implants based in estrogenic substances and trembolone acetate appear to enhance the normal thyroid activity (Mader and Kreikemeier, 
2006). In the present study, Synovex implants were used. Some studies reported that Plasma $\mathrm{T}_{4}$ levels were higher in Synovex implanted-steers in comparison to non-implanted steers, but no differences were found in $\mathrm{T}_{3}$ levels (Kahl et al., 1978).

\section{CONCLUSIONS}

Cooling system improved steer welfare under feedlot conditions, as showed by a reducing in respiratory frequency and body surface temperature. Nonetheless, the productive performance was not increased with the cooling, making it not financially viable.

\section{ACKNOWLEDGMENTS}

We want to thank to the herd owner Juan Carlos Reynoso and the manager Ruben Fregoso for their help and cooperation during the trial. The study was financially supported by Universidad Autónoma de Baja California, México.

\section{REFERENCES}

BROWN-BRANDL, T.M.; NIENABER, J.A.; EIGENBERG, R.A. et al. Thermoregulatory responses of feeder cattle. St. Joseph: American Society of Agricultural Engineering, 2002. (Paper no. 024180).

CARSTENS, G.E.; JOHNSON, D.E.; ELLEMBERGER, M.A. Energy metabolism and composition of gain in beef steers exhibiting normal and compensatory . In:___Energy metabolism of farm animals. Roma, Italy: European Association of Animal Production, 1989. p.131. (Publ. no. 43).

COLLIER, R.J.; DAHL, G.E.; VANBAALE, M.J. Major advances associated with environmental effects on dairy cattle. J. Dairy Sci., v.89, p.12441253, 2006.

COLLIER, R.J.; DOELGER, S.G.; HEAD, H.H. et al. Effect of heat stress during pregnancy on maternal hormone concentrations, calf birth, and postpartum milk yield of Holstein cows. J. Anim. Sci., v.54, p.309-316, 1982.

CORREA-CALDERÓN, A.; ARMSTRONG, D.V.; RAY, D.E. et al. Thermoregulatory responses of Holstein and Brown Swiss heat stressed dairy cows to two different cooling systems. Int. J. Biometeorol., v.48, p.142-148, 2004a.
CORREA-CALDERÓN, A.; YAÑEZ, V.; VERDUGO, F. et al. Efecto de un sistema de enfriamiento a espacio abierto en la eficiencia productiva de novillos Holstein durante el verano. Interciencia, v.29, p.86-88, 2004b.

CORREA-CALDERÓN, A.; YAÑEZ, V.M.; VERDUGO, J.F. et al. Physiological and productive response of feedlot steers with an open space cooling system in an arid, dry climate. Tec. Pecu. Mex., v.45, p.345-354, 2007.

DAVIS, M.S.; MADER, T.L.; HOLT, S.M. et al. Strategies to reduce feedlot cattle heat stress: effects on tympanic temperature. J. Anim. Sci., v.81, p.649-661, 2003.

EFFECT of environment on nutrition requirements of domestic animals. Washington, DC.: National Academy of Sciences, 1981. p.57-66.

EIGENBERG, R.A.; BROWN-BRANDL, T.M.; NIENABER, J.A. Dynamic response of feedlot cattle to shade and no-shade. St. Joseph: American Society of Agricultural Engineering, 2002. (Paper no. 024050).

GARCÍA, E. Modificaciones al sistema de clasificación climática de Köppen (para adaptarlo a las condiciones de la República Mexicana). 2.ed. México, DF: Instituto de Geografía, Universidad Autónoma Nacional de Mexico, 1985. 246p.

GARNER, J.C.; BUCKLIN, R.A.; KUNKLE, W.E. et al. Sprinkled water and fans to reduce heat stress of beef cattle. Am. Soc. Agric. Eng., v.5, p.99101,1989 .

HAHN, G.L. Dynamic responses of cattle to thermal heat loads. J. Anim. Sci., v.77, suppl.2, p.10-20, 1999.

HERSOM, M.J.; HORN, G.W.; KREHBIEL, C.R. et al. Effect of live weight gain of steers during winter grazing. I. Feedlot performance, carcass characteristics, and body composition of beef steers. J. Anim. Sci., v.82, p.262-272, 2004a.

HERSOM, M.J.; WETTEMAN, R.P.; KREHBIEL, C.R. et al. Effect of live weight gain of steers during winter grazing. III Blood metabolites and hormones during feedlot finishing. J. Anim. Sci., v.82, p.2059-2068, 2004b.

KAHL, S.; BITMAN, J.; RUMSEY T.S. Effect of Synovex-s on growth rate and plasma thyroid hormone concentrations in beef cattle. J. Anim. Sci., v.46, p.232-237, 1978. 
MADER, T.L.; HUNGERFORD, L.L.; NIENABER J.A. et al. 2001. Heat stress mortality in Midwest feedlots. J. Anim. Sci., v.79, suppl.2, p.33, 2001.

MADER, T.L.; HOLT, S.M.; HAHN, G.L. et al. Feeding strategies for managing heat load in feedlot cattle. J. Anim. Sci., v.80, p.2373-2382, 2002.

MADER, T.L.; KREIKEMEIER, W.M. Effects of growth-promoting agents and season on blood metabolites and body temperature in heifers. $J$. Anim. Sci., v.84, p.1030-1037, 2006.

MCGUIRRE, M.A.; BEEDE, D.K.; COLLIER, R.J. et al. Effects of acute thermal stress and amount of feed intake on concentrations of somatotropina, insulin growth factor (IGF-1) and IGF-2, and thyroid hormones in plasma of lactating Holstein cows. J. Anim. Sci., v.69, p.2050-2056, 1991.

MITLÖHNER, F.M.; MORROW, J.L.; DAILEY, J.W. et al. Shade and water misting effects on behavior, physiology, performance, and carcass traits of heat-stressed feedlot cattle. J. Anim. Sci., v.79, p.2327-2335, 2001.

MORRISON, S.R.; GIVENS, R.L.; LOFGREEM, G.P. Sprinkling cattle for relief from heat stress. $J$. Anim. Sci., v.36, p.428-431, 1973.

MORRISON, S.R.; LOFGREEN, G.P.; GIVENS, R.L. Sprinkling cattle for heat stress relief: breed differences and sprinkling interval. In: INTERNATIONAL LIVESTOCK ENVIRONMENT SYMPOSIUM, 1974, Lincoln. Proceedings..., Lincoln, Nebraska:. American Society Agricultural Engineering, 1974. p.310-315.
NUTRIENT requirements of beef cattle. Washington, DC: National Academy of Sciences, 1996. p.134-143.

NIENABER, J.A.; HAHN, G.L. Engineering and management practices to ameliorate livestock heat stress. In: INTERNATIONAL SYMPOSIUM OF THE CIGR. NEW TRENDS IN FARM ANIMALS BUILDING, 1., 2004, Evora. Proceedings... Evora, Portugal: GIGR, 2004. p.1-18.

STEEL, R.G.D.; TORRIE, J.H. Principles and procedures of statistics. A biometrical approach. 2.ed. Singapore: McGraw-Hill,1981. p.491-493.

ST-PIERRE, N.R.; COBANOV, B.; SCHNITKEY, G. Economic losses from heat stress by US livestock industries. J. Dairy Sci., v.86, p.E52-E77, 2003.

TRENKLE, A. Mechanisms of action of estrogens and androgens on performance of cattle - Hormonal basis. In: IMPACT OF IMPLANTS ON PERFORMANCE AND CARCASS VALUE OF BEEF CATTLE, SYMPOSIUM, 1997, Stillwater. Proceedings... Stillwater, OK: Oklahoma Agricultural Experiment Station, Oklahoma State University, 1997. p.15-22.

WEST, J.W. Interactions of energy and bovine somatotropin with heat stress. J. Dairy Sci., v.77, p.2091-2102, 1994. 